Media Industries 6.2 (2019)

\title{
Over-the-Top Video Services in India: Media Imperialism after Globalization
}

\author{
Scott Fitzgerald \\ CURTIN UNIVERSITY ${ }^{1}$ \\ s.fitzgerald [AT] curtin.edu.au
}

\begin{abstract}
This article reviews the rapid growth of over-the-top (OTT) video services in India, such as Voot, Hotstar, Netflix, and Amazon, and places their development in the context of the dominant trends and business models at the international level. The expansion of such services in India, a country that ranks as the second largest market globally for "tech companies" such as Facebook and Amazon, raises questions about conceptions of development, participation, diversity, and power used to understand platformization in areas such as communication and culture. The article assesses the specific dynamics of platform growth in the country in relation to the interplay between new digital infrastructures, including fiber-optic cables, broadband networks, and smartphones; corporate strategies among small and large, local and international players; and state policy and regulation, which seeks to both address concerns about economic, political, and cultural security and spur the socioeconomic development of India among "wired" nations.
\end{abstract}

Keywords: OTT Video, Infrastructures, Platforms, Business Models, Media Imperialism

The development of internet-distributed video, known as over-the-top (OTT) video services, marks a disruptive intervention in the markets for audiovisual content across the world. The scale of the market ambitions involved has led to renewed debate about the concept of "media imperialism" as a framework for understanding the international communication order. On the one hand, liberal and futurist accounts position disruptive platforms as startup businesses favoring amateur production and supporting "new voices" as a counterpoint to the hegemony of legacy media actors. On the other hand, critical political economists of communication argue that the age of media imperialism has returned with a vengeance, given the global market power of major US-based "IT" or "tech companies" and the support those companies receive from the US state. ${ }^{2}$ Given the potentials of its large and growing user-base, India has emerged as the latest territory ripe for the global expansion of US OTT video platforms. US tech companies are well aware that "Despite infrastructural challenges, 
India is home to 460 million internet users, second only to China at over 721 million, in addition to being a beehive of local content production." ${ }^{3}$ Consequently, the Hollywood Reporter has claimed, "India Will Be a Key Battleground for Amazon and Netflix."4

Currently, it is the open platform YouTube that remains the largest platform supplying video content in India, carrying the media libraries of major Indian broadcasters. Nonetheless, the number and footprint of OTT operations have increased significantly in the last three years. There are now more than thirty broadcaster-owned platforms, telecom operators, and global players (like Netflix and Amazon Prime) offering advertisement video-on-demand (AVOD) and subscription video-on-demand (SVOD) services. Despite infrastructural challenges and uneven purchasing power, India is projected to become the second largest online videoviewing audience by 2020 , with some 500 million people viewing videos online-of these, some 355 million people are expected to watch via OTT video services. ${ }^{5}$ This article seeks to map changes taking place in the emerging sector of OTT video in India and to place these changes in the context of the dominant trends and business models propounded at the international level. Having charted the development of the OTT market in India and the interplay of digital infrastructures, corporate strategies, and state policy and regulation, this article considers current debates on media imperialism and the geopolitics of information in the context of OTT video in India. A key point advanced is that notwithstanding the international dimension, we should not lose sight of the role of large Indian telecommunications service providers (TSPs) like Reliance Industries Ltd. (RIL) and their role in formulating concentrations of power in different parts of the value chain.

\section{OTT and US "Tech Corporations"}

At the global scale, established media industries have increasingly needed to deal with the strategies of "tech sector" actors and their attempts to interlink consumer access to cultural commodities into their own value chains. To some extent, such changes replicate the form of relationship between large capitals and small capitals long characteristic of the cultural industries. ${ }^{6}$ However, it has become evident that the future of cultural enterprises is increasingly influenced by a handful of powerful communication companies that employ an "arm's length" approach to content production and whose business strategies are not driven primarily by a concern to develop the cultural industries per se. As a consequence, the assumed foundations of media and cultural production and distribution have shifted significantly with the rise of digital giants such as Google, Apple, Microsoft, Amazon, Netflix, and Facebook. As their market power has grown, their products, platforms, and services are becoming a central subject of litigation, policy reformulation, and regulatory investigation around the globe.

Arguably, the outsourcing of content production in the 2000s helped to support and sustain the proliferation of digital media services and platforms in accordance with the emergence of amateur producers and user-generated content. Thus, some scholars have argued that the rise of user-generated media content through Google's YouTube and other social media illustrates the need to reconceptualize the nature of media audiences-from active audiences to prosumers. ${ }^{7}$ However, notwithstanding the potentials of what Cunningham and Craig dub as "commutainment," it has also been conceded that "it is notable how rapidly the 
new content production environment has institutionalized along similar lines to the established TV production culture, which provides evidence for continuity and against radical change." 8

For other scholars, the convergence between tech companies and outsourced content production via digital platforms also represents an essential change in the industrial structure of media, albeit a less utopian one. Hesmondhalgh, for example, has raised concerns that "Until recently, tech corporations were mainly involved in distribution rather than production. But now, instead of simply delivering TV shows, music and films onto our devices and screens, major firms are sinking huge amounts of money into the content itself." Hesmondhalgh argues that these developments are best seen as "a wholesale media power grab by the tech sector." Hesmondhalgh notes the close, symbiotic relationship between the media and electronics sectors but avers that "the new tech oligopoly has even more power than the electronics corporations and media giants." 10

The market power of digital media platforms has been amassed under unique regulatory regimes associated specifically with information technology. That is, the digital economy has been allowed to operate essentially as a freeport where regulation is limited to the technical standards of the World Wide Web. Thus, unlike the legacy media and telecommunications companies, the tech giants (Google, Apple, Facebook, Amazon, and Microsoft) have been very lightly regulated in terms of public interest responsibilities for what is carried in their systems and in terms of market competition and anti-monopolistic behavior. As a consequence, these tech firms have acquired vast resources, international range, and monopoly power. They have also played a key role in integrating previously disparate media markets for content, communication, advertising, market information, and surveillance. Consequently, their foray into content distribution is inextricably linked, and underwritten, by their capacity to collect and sell data about their users.

As part of the "new communications world," the presence of tech companies in "traditional" media content provision continues to expand and deepen. In early 2016, Netflix announced that it was launching its service in 130 countries, tripling the number of markets where it operates and leading to what the company's CEO described as "the birth of a new global internet TV network."11 In late 2016, Amazon responded with a global rollout of its streaming video service to approximately two hundred countries which serviced sixty-five million Amazon subscribers worldwide. Netflix has since increased its coverage to almost two hundred countries and maintains its lead with 139 million subscribers worldwide. ${ }^{12}$ In addition to quickly increasing their distributional reach, a key strategic strength in the media economy, US-based tech firms have been sinking large-scale investment into content production. Amazon invested US\$4.5 billion in content in 2017 but noted that its global video streaming service would require an additional US\$1 billion to US\$2 billion investment video content. Netflix raised its content budget to US\$7 billion in fiscal 2017 and announced it would invest US\$7 billion to US\$8 billion in content in 2018 .

Analysts projected that Amazon's investment in content will reach US\$ 7.5 billion in $2019 .{ }^{13}$ Netflix has signaled that it seeks to have at least 50 percent original shows by the end of 2020 and, to achieve this, would increase its 2019 investment in content to US\$15 billion, of which 85 percent would be original content. ${ }^{14}$ To put this in context, the merged Disney/Fox was 
projected to spend US\$22 billion on content in 2018, whereas the merged Comcast/Sky was expected to spend US\$21 billion in $2018 .^{15}$

While both Apple and Facebook announced US\$1 billion investments in original video content in 2017, YouTube has signaled that it was not following the path of Netflix and Amazon. A YouTube spokesperson noted that this was "in part because it's harder to financially support such expensive shows with an ad-supported service."16 This orientation was later confirmed in the strategy for YouTube Originals in late 2018. ${ }^{17}$

Amanda Lotz has argued about the particular industrial and viewer protocols of internetdistributed video, built on high costs of long-form, scripted production and need to be seen as distinct from the emerging internet-distributed television industry that utilizes amateurand user-generated content. Lotz contends that the two should be seen as evolving into separate industries. ${ }^{18}$

The vast sums that Netflix is spending on long-form, scripted production means that the company has comparatively measly profits and negative free cash flow. Yet, as with the other so-called FAANG (Facebook, Amazon, Apple, Netflix, and Google) companies, Netflix has maintained exceptional financial markets support, an "exorbitant privilege" given to the communication strategies of the tech sector. ${ }^{19}$ From 2012 to 2017, Google's holding company Alphabet rose almost 200 percent, Amazon more than 300 percent, Facebook 800 percent, and Netflix (albeit much smaller) increased its capitalization by more than 2,000 percent. $^{20}$ Despite significant share market fluctuations, tied to missed subscription growth targets and increased content investment, Netflix's (and Amazon's) share price continued to rise in 2018.

By the end of 2018, Netflix's market capitalization had reached US\$134.5 billion (a fraction of Amazon's US\$790.85 billion). By contrast, Facebook's stock declined by 25 percent (to US\$365 billion), a fact that should caution against uncritically lumping together the fortunes of "tech corporations" that have a different reliance on OTT TV, social network, and online retailing business models. ${ }^{21}$

In reviewing the prevailing business models of OTT video in the United States, Lotz (2017) argues that two key transformations are evident. First, three-quarters of portals in the United States have adopted a subscriber-funded revenue model where "foremost, the aim of creating content that attracts subscribers leads to programming very different than the aim of creating content that will gather a mass of advertiser-desired eyeballs." ${ }^{22}$ The second transformation is the deepening of vertical integration strategies, as television studios seek greater control of production and distribution of their programming. Lotz suggests that OTT portals "further reconfigure the strategy of vertical integration. Distinctions between producers and distributors blur in an environment of internet-distributed television in ways that produce notable consequences for the creative goods these industries develop." 23

In describing the first change associated with OTT or internet-distributed television portals, Lotz draws on the theorization of models and logics put forward by Miège and other scholars. ${ }^{24}$ Here, two dominant models (publishing and flow) and three intermediate models (the club, the metered economy, and information brokerage) of media business models are commonly identified. ${ }^{25}$ In the publishing model (e.g., books, music, DVDs), an editor/producer uses a catalog of cultural artifacts as a means of mediating between various creative/artistic submissions, industrial production, and the uncertainty of market demand. Here, the final 
consumer contributes directly to the financing of the content they consume (a book through Amazon or a music track on iTunes) by purchasing a copy that they can own (the purchasing of a cinema ticket is essentially a copy rental by the end consumer).

The flow model (e.g., broadcasting) responds to uncertainty by producing "a constant flow of products as a packaged service and where speed and range of distribution is critical." ${ }^{26}$ Consumers neither possess nor directly pay for continuous programming, since a third party, usually advertisers, provides funding indirectly. More recently, Lotz's argument is that a subscriber model of generating revenue from media goods, or a "club logic," is predominant in the OTT sector in the United States. Here, a subscriber-funded revenue model transforms many practices previously associated with flow model advertiser-support or publishing models in the media industries. While earlier discussions of the club logic emphasized a combination of direct and indirect payments under the "hegemony of the distribution function," Lotz contends that the "affordance of nonlinearity adjusts viewer experience, but the affordance of enabling data collection also adjusts the strategies portals can use in developing and curating their libraries." ${ }^{27}$ Table 1 summarizes the two dominant models and the intermediate club models below.

Table 1. Distinction between Flow, Publishing, and Club Models.

\begin{tabular}{|c|c|c|c|}
\hline $\begin{array}{l}\text { Model } \\
\text { characteristics }\end{array}$ & Flow & Publishing & Club \\
\hline 1. Sectors & $\begin{array}{l}\text { Broadcast TV } \\
\text { and radio }\end{array}$ & Books, Music, and Film & $\begin{array}{l}\text { Over-the-top television, } \\
\text { subscription video-on- } \\
\text { demand cable }\end{array}$ \\
\hline $\begin{array}{l}\text { 2. Dominant } \\
\text { payment } \\
\text { method }\end{array}$ & $\begin{array}{l}\text { Indirect adverting } \\
\text { revenue and state } \\
\text { subsidies }\end{array}$ & Direct sales to consumer & $\begin{array}{l}\text { Consumer purchases access } \\
\text { to collection of goods and } \\
\text { enjoys unlimited consumption }\end{array}$ \\
\hline 3. Content & $\begin{array}{l}\text { Continuous provision } \\
\text { of ephemeral } \\
\text { prototypes }\end{array}$ & $\begin{array}{l}\text { Discontinuous provision of } \\
\text { durable, individual copies }\end{array}$ & $\begin{array}{l}\text { Continuous provision of a } \\
\text { catalog of cultural goods }\end{array}$ \\
\hline $\begin{array}{l}\text { 4. Central } \\
\text { coordination } \\
\text { function }\end{array}$ & $\begin{array}{l}\text { Programmer } \\
\text { construction of liner } \\
\text { schedule }\end{array}$ & Editorial maintenance of catalog & $\begin{array}{l}\text { Portal curates, purchasing } \\
\text { rights, or creating content } \\
\text { that can be accessed at } \\
\text { will allowing for nonlinear } \\
\text { consumption }\end{array}$ \\
\hline $\begin{array}{l}\text { 5. Creative labor } \\
\text { remuneration }\end{array}$ & $\begin{array}{l}\text { Steady employment } \\
\text { based on contracts } \\
\text { and salaries: } \\
\text { broadcast workers, } \\
\text { technicians, } \\
\text { journalists, hosts, etc. }\end{array}$ & $\begin{array}{l}\text { Small core workforce flanked by } \\
\text { large pool of writers, directors, } \\
\text { composers, artists, and so on } \\
\text { remunerated through royalties }\end{array}$ & $\begin{array}{l}\text { Computer/data scientists } \\
\text { improve recommendation } \\
\text { algorithms, user experience } \\
\text { interface, feature, and } \\
\text { functionality. Creative talent } \\
\text { (externally contracted) makes } \\
\text { content }\end{array}$ \\
\hline $\begin{array}{l}\text { 6. Industrial } \\
\text { structure }\end{array}$ & $\begin{array}{l}\text { Quasi-industrial, } \\
\text { vertical integration, } \\
\text { and central planning. } \\
\text { Managerial control } \\
\text { of all elements in the } \\
\text { value chain }\end{array}$ & $\begin{array}{l}\text { Oligopoly with a competitive } \\
\text { fringe-few large companies, } \\
\text { shared infrastructure (printing, } \\
\text { studios, etc.), project-based } \\
\text { networks, and small firms }\end{array}$ & $\begin{array}{l}\text { Oligopoly with a competitive } \\
\text { fringe-few large companies, } \\
\text { shared infrastructure } \\
\text { (printing, studios, etc.), } \\
\text { project-based networks, and } \\
\text { small firms }\end{array}$ \\
\hline $\begin{array}{l}\text { 7. Market } \\
\text { structure }\end{array}$ & $\begin{array}{l}\text { Tight oligopoly, } \\
\text { vertical integration }\end{array}$ & $\begin{array}{l}\text { Oligopolistic core } \\
\text { surrounded by small firms }\end{array}$ & $\begin{array}{l}\text { Emerging oligopoly, vertical } \\
\text { integration }\end{array}$ \\
\hline
\end{tabular}

Source. Adapted from Winseck (2011, p. 32) and Lotz (2017). 


\section{OTT Video in India}

According to the Telecom Regulatory Authority of India (TRAI), the possibilities and challenges of the OTT sector in India can be differentiated via the essential functions of the associated services and applications. The TRAI 2015 Consultation Paper on Regulatory Framework for Over-the-top (OTT) Services conceptualized three types of OTT apps in the Indian market:

1. Communication services (messaging and voice services);

2. Application ecosystems, linked to social networks and e-commerce;

3. Video/audio content.

When it comes to video/audio content, YouTube remains by far the leading online video platform in India. ${ }^{28}$ In September 2011, the online platform was joined by Zee's dittoTV, the Singapore-based Spuul, which reaches out to the South Asian diaspora, and Sony LIV. India quickly moved to second place internationally in terms of YouTube video uploads, and by the end of 2013 was accounting for 58 percent of online video viewership in India. However, it should be noted that four of the top ten YouTube channels in India were Hindi General Entertainment Channels-"StarPlus," "Colors TV," "Zee TV," and "SET India." ${ }^{29}$ YouTube also sought to entice regional language channels to use the platforms as a second window for the network broadcasts. ${ }^{30}$ Sony LIV, for example, was offered via YouTube channel and on its app website.

From twelve million OTT video-on-demand subscribers in 2014, the number of subscribers was predicted to grow to 105 million by $2020 .{ }^{31}$ Such "blue sky" exponential growth predictions have been a common feature of India's expanding media economy over the past twenty years. Nonetheless, by this measure, the digital video subscription market is estimated to be worth around Rs. 4,000 crore (US\$578 million) by 2020, while OTT and digital advertising is estimated to be worth Rs. 18,500 crore (US\$2.675 billion). This compares to a projection of approximately Rs. 109,000 crore (US\$15.76 billion) for the entire TV industry, or 3.6 percent and 17 percent, respectively. ${ }^{32}$ By 2015 , the number of major OTT video services had increased to twelve (Hotstar, Spuul, Netflix, Muvizz, Hooq, Eros Now, Box TV, Sony LIV, YuppTV, dittoTV, Ogle, Hungama Play), and at the end of 2016 this number had increased to approximately thirty (see Table 2). ${ }^{33}$

The development of OTT video platforms has seen increased investment in content, and for some industry segments and companies, this has led to significantly higher revenues. OTT content can be roughly categorized as catch-up TV (including syndicated content), live sports, and originals. From a pricing and subscription model perspective, "live sports draws a premium followed by originals and then catch-up TV." ${ }^{\prime 34}$ With regard to sport, Twenty-First Century Fox-backed Star India submitted a global bid for Indian Premier League (IPL) cricket tournament rights and is running the digital rights of the IPL through its OTT platform Hotstar. Star bid US\$2.55 billion for the five-year contract, the equivalent of paying more than US\$8 million or Rs. 54.5 crore per match. Star India has created a near-monopoly cricket sports rights, as it also owns the rights to all Board of Control for Cricket in India (BCCI) 


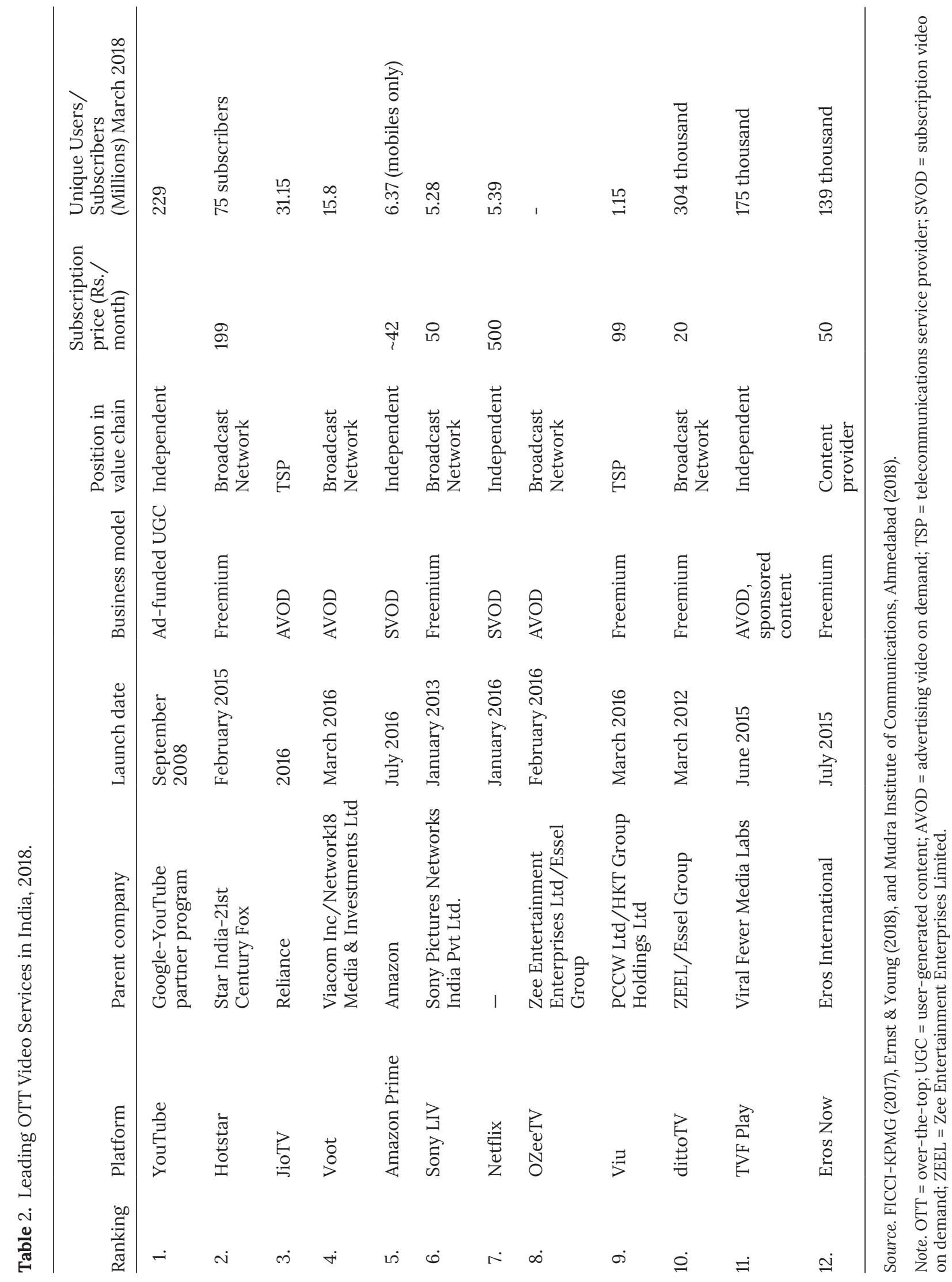


matches (including one day internationals, tests, and T20 games). ${ }^{35}$ Such deals clearly further shift the international balance of cultural influence and content flow in this sport. ${ }^{36}$

This expansion of the OTT sector in India also includes global leaders, such as Netflix and Amazon Prime, as well as major broadcast network-backed platforms, such as VOOT (Viacom 18 ) and OZeeTV (Zee TV). The major US OTT players, Netflix and Amazon, have been conspicuously active. Amazon has invested about one-fourth of its Rs. 2,000-crore India budget in local production houses, including those of filmmakers Farhan Akhtar and Anurag Kashyap. That is more than the annual budgets of market leader Hotstar, Eros Now, SonyLIV, Voot, and Balaji Telefilm's ALTBalaji. Overall, Amazon has signed up at least fifteen production houses and digital content creators. It has also bought exclusive streaming rights to two of the highest grossing Indian films: Dangal, a wrestling movie, and Baahubali 2 (BB2), an epic fantasy action film. The company has also leveraged the popularity of cricket by launching Inside Edge, the fictional story of the Mumbai Mavericks, a T20 cricket franchise playing in the Powerplay League; in September 2017, it commissioned another Indian film focusing on cricket and corruption. ${ }^{37}$

Telecommunications providers have also moved into the OTT business through the provision of syndicated content offerings on the likes of Jio Apps, Airtel Wynk, and so on. ${ }^{38}$ Critically, the digital infrastructure witnessed a significant step forward with the wide rollout of high-speed 4G services in 2015-2016. This increased availability of broadband is obviously essential to a host of new services including OTT video. The Federation of Indian Chambers of Commerce and Industry, in partnership with the international accounting firm KPMG, noted in 2017 that

Rising internet and broadband penetration, declining data charges, coupled with the proliferation of internet enabled mobile phones, led to data consumption levels increase manifold, driven by offers by the new entrant, Reliance Jio; which were quickly followed by major competitors Idea, Vodafone and Airtel. ${ }^{39}$

Despite the relatively small size of the market, the FICCI-KPMG report, Media for the Masses, is enthusiastic about the potentials of the OTT sector, providing a detailed report on the factors attracting new market players. These include four elements connected with digital infrastructure and access: ${ }^{40}$

1. Pipes: The development in digital infrastructure, including state investment under the Digital India initiative and private initiatives around Wi-Fi (e.g., by Google) and broadband rollout by cable multiple system operators (MSOs), has increased internet penetration and speed, driving digital consumption (with 112,000 km of optical fiber laid and 2,500 free Wi-Fi hotspots).

2. Data: Price wars associated with the rollout of $4 \mathrm{G}$ by major TSPs have led to a marked reduction in data tariffs. Data costs fell from around Rs. 250 per GB to Rs. 10 and are expected to remain comparatively lower after loss-leading strategies of Reliance Jio and other firms come to an end.

3. Devices: The declining price and increased screen size and market penetration of smartphones have resulted in these devices emerging as an alternative screen for 
media consumption. Urban consumers have been early adopters of video, especially in the age group fifteen to thirty-four, and the mobility of smartphones is conducive to increased media consumption, particularly during longer commute times in metropolitan cities.

4. Habits: There has been an increase in consumption of video online through mobile devices. FICCI-KPMG projects that the number of video-capable devices and connections will grow 2.2-fold between 2016 and 2021, reaching eight hundred million in number. Internet consumption via mobile data constitutes 15 percent of all internet consumption in 2016 , and this is expected to rise to 30 percent by $2021{ }^{41}$

Evans et al. provide a note of caution regarding internet access and online viewing, observing that "Geographical limits to accessing the physical infrastructure, the cost of data programs and a deficit in local language content have all impeded expansion of the online population." ${ }^{" 2}$ TRAI figures for internet/broadband subscribers were 422.19 million in 2017 (wired internet subscribers were 21.58 million and wireless internet subscribers were 400.62 million, of which 276.52 million were broadband subscribers). ${ }^{43}$ These figures compare to the 10.92 million people subscribed to broadband connections in $2010 .{ }^{44}$ These figures were significantly bolstered by the rollout of digital cable networks, which make up the majority of "internet" subscriptions. ${ }^{45}$ Even so, this still represents less than 32 percent of India's estimated 1.34 billion population which supports ambitions for market growth but also indicates infrastructure and access constraints well into the future. Equally, although the smartphone user-base in India crossed three hundred million in 2017 and the share of mobile phone users who use a smartphone in India has risen to 33.4 percent, ${ }^{46}$ Evans et al. argue that "smartphone ownership figures do not easily equate to high speed service subscriptions, however," given that active $3 \mathrm{G}$ and $4 \mathrm{G}$ subscribers figures remain noticeably lower. ${ }^{47}$

By 2021, video-capable devices have been projected to constitute 59 percent of total mobile connected devices with 814 million consumers, from 35 percent currently. ${ }^{48}$ Although still socially and geographically restricted, growth in mobile wireless internet users has meant that mobile video viewership has become a "mass" medium, a development that makes this market attractive to the advertising industry. FICCI-KPMG projects continuous growth on digital ad spends, with the digital advertising market envisaged to quadruple from Rs. 76.9 billion in 2016 to Rs. 294.5 billion by 2021 (a growth trajectory of 30.8 percent). ${ }^{49}$ While advertisers have incorporated online video advertising as a means to complement existing TV-based advertising strategies, many view OTT services as an opportunity to provide content on an additional platform "rather than as a threat to their existing business." ${ }^{.50}$ As opposed to the US OTT video market, advertising remains the mainstay of income for the leading OTT platforms in India. This is the case even for those pursuing a so-called freemium model, where some content is available free (ad-supported) and premium content is charged. Moreover, only a very small percentage of the audience is made of subscribers even for the freemium and subscription operations. ${ }^{51}$

This balance among advertising versus subscription models has remained relatively stable over the last four years, with ten of India's top twelve OTT video platforms (see Table 2) based on either AVOD services or freemium. Sabherwal and Dsouza note that India's OTT sector is dominated by advertising-led revenue models (90 percent), while subscription-led 
models fund a paltry two to three percent of the sector's revenue with current estimates that subscriptions will reach 9 percent by $2020{ }^{52}$ FICCI-KPMG's overall analysis is that the recent "surge in digital consumption" is forcing existing players to reexamine their business models. ${ }^{53}$ For example, Sony LIV moved in 2015 from an AVOD model to a freemium model. At the time, Sony's Head of Digital Business and Executive Vice President Uday Sodhi noted,

The idea is to move to a fee-based subscription model over a period of time and see what content can be monetised with advertising and what content can be charged to the customer. We will have a combination of these two models going forward ... We are broad-basing our audience. Currently, most of our audience views Sony LIV as a means of catching up some of the stuff that they have missed on television. We are now offering them original content which they can view on digital. ${ }^{54}$

While other players such as Zee Entertainment Enterprises Limited (ZEEL) have adjusted their offerings through AVOD and freemium platforms (in February 2018 it combined its AVOD-based OZeeTV and freemium-based dittoTV into the single Zee5 platform), new AVOD platforms such as Network18 and Viacom's Voot state that they view advertising models as an initial strategy facilitating market entry, with a subscription model to be implemented once the customer base has been consolidated. The necessity for this shift derives from the fact that advertising revenues are not currently covering content and customer acquisition costs. Thus, OTT platforms need to generate significant revenues from the subscription services, especially if they intend to offer differentiated content from other providers. While "must carry" regulations force a broadcaster in India to share content across all platforms that demand it, no such law exists for digital media. Raghav Anand, Director, Media \& Entertainment at Ernst \& Young, has noted,

Most of these players are betting on the fact that as the market matures, the consumers would start paying for content. Also, the expectation is content differentiation/uniqueness would drive consumers to pay. With the digital payment ecosystem maturing and bandwidth availability, there are pockets among different digital consumers who have slowly started to pay. However, the inflection point on subscription is a good three to four years away. ${ }^{55}$

Other industry participants have expressed skepticism about an imminent shift to subscriptionbased models, due to consumers' reluctance to pay and the widespread availability of pirated content: "Content like 'Narcos' and 'Game of Thrones' [GoT] are available on pirated sites. As long as that exists, getting the consumer to pay will be very difficult. There has to be better legislation so that such content is protected." ${ }^{\prime 56}$ Recent arrests of STAR TV-associated staff in Mumbai for pirating Season 7 of GoT illustrate the continuing problem of product leakage. ${ }^{57}$ Another issue is that in India the costs of an OTT subscription are twice as high as the costs of cable and DTH subscriptions (the reserve of the relative cost structure in the United States). Nonetheless, complete SVOD platforms such as Netflix, Amazon Prime, and the OTT venture from Mumbai-based Balaji Telefilms (ALTBalaji) all reflect a belief that exclusive content will entice consumers to pay for content in the medium to long term. ${ }^{58}$

One approach to the sustainability of revenue streams is a deepening of vertical integration strategies. Some analysts in India predict that the "market will consolidate among three to four major OTT players who would have picked up specific market niche/differentiation around major content genres-sports, kids, movies, young adult, etc." ${ }^{\text {In }}$ In this consolidation 
process, TSPs are expected to have a major role. Their presence in the market is compelled by the fact that data revenues will increase by nearly 350 percent to Rs. 955 billion by 2021 and video consumption is expected to contribute more than 60 percent of data traffic. ${ }^{60}$ A reliance on OTT content as a loss-leading strategy to boost data revenue would become unsustainable at this level, since currently only 0.5 to 1 million pay for content out of hundred million digital users. ${ }^{61}$ Equally, FICCI-KPMG argues that the development of a payper-view SVOD market would have to be facilitated by the established payment network of telecom operators. As such, "A combination of the distribution strength of telecom operators; combined with content creation capabilities of large media houses, would result in an end to end capability." ${ }^{2}$

With the acquisition of Time Warner by AT\&T taken to represent the global model, FICCIKPMG also observes that RIL's controlling investments in Network 18, owner of the Voot OTT platform, combined with the TSP capabilities of Reliance Jio could set the model for future merger and acquisition activity in India. ${ }^{63}$ The Indian state has expedited the restructuring and consolidation of the telecommunications sector over the past two decades, first through liberalization policies in 2001 and then through facilitating the entry of Reliance Industries, a petrochemical conglomerate owned by Mukesh Ambani, into the sector in 2010. Reliance Jio's price war strategy in 2016 drove increases in data usage and reduced the number of TSP operators to five (from fifteen in 2010). ${ }^{64}$ Since Vodafone, Airtel, and Reliance Jio are all offering OTT services as part of bundled service packages, the development of the OTT market in India cannot be separated from corporate and state strategies in the telecommunications sector. Other forms of international integration are also taking place: with Ernst \& Young citing development of HOOQ between Sony Pictures, Warner Brothers, and Singtel as an exemplar of studio and telecom joint venture partnership:

With increasing competition and challenges around monetization, companies are increasingly looking at partnerships in order to mitigate market constraints. Many global players who are entering into the Asian/Indian market are looking at local partnerships in order to provide "Glocal" offerings. The market is expected to witness more vertical and horizontal partnerships, acquisitions to drive synergies. ${ }^{65}$

The entry of major global TSPs and content producers into India's OTT market has inevitably led to stock market speculation (and possibly manipulation), as when stories emerged in August 2017 that Eros would sell its entire library, including Eros Now, to Apple, Netflix or Amazon for US\$1 billion. ${ }^{66}$ In fact, Reliance Industries took just a 5 percent equity stake in Eros in 2018, to add to its existing 25 percent of ALTBalaji, while it also took controlling stakes in India's two largest cable TV and broadband companies as part of its bid to create a fiber-to-the-home (FTTH) broadband service called JioGigaFiber. ${ }^{67}$

\section{Media Imperialism Goes Over the Top}

The rise of global media platforms and the new formats, practices, and avenues that they facilitate for accessing media content has compelled media scholars to revisit debates about media imperialism and long-term trends in media globalization. Exponents of a "strong" 
version of center-periphery media imperialism have characterized the global expansion of video platforms as "platform imperialism." ${ }^{68}$ Scholars such as Cunningham and Craig, however, have argued that platforms such as YouTube facilitate, rather than control, content and thereby permit much greater diversity of language and cultural content, creator, and service firm participation. While they are in accordance with Hesmondhalgh's analysis that there has been little or no content regulation of YouTube as its use proliferates globally, they argue that YouTube content is "initially primarily amateur" and generated under "very different intellectual property (IP) regimes" than the strong copyright regimes through which traditional media hegemony has been exercised. ${ }^{69}$ Moreover, Cunningham and Craig also note that India constitutes one of the largest emerging non-Western online spaces in the world, demonstrating various forms of intense localization.

Punathambekar and Mohan argue that current debates about platform imperialism often have a "striking similarity to those made during ... proliferation of transnational satellite television channels [which] raised anxieties concerning conglomeration, cultural homogenization, and the erosion of national- cultural identities." ${ }^{70}$ In India, in the 1990s apprehensions about cultural and media imperialism were evident in the state's attempts to regulate the development of the cable and satellite industry. As Narayan and Arya observe, the introductory section of the Cable Television Networks (Regulation) Act, 1995 "explained the need for such regulation on the ground that the programs which were being projected on satellite channels at the time were predominantly Western and alien to Indian culture and way of life."71

The Government of India's anxieties about platform operations are apparent, yet in India the regulatory response to the OTT video platforms appears quiet distinct. ${ }^{72}$ In response to public concerns about content on video streaming platforms, the Government of India has reaffirmed that, as services available over the public internet, OTT platform operators do not require a license to operate and that sufficient safeguards are available in the Information Technology Act, 2000 which "allows the government and the courts to direct ISPs, on whose networks users access [OTT video services], to either block or take-down [content] ... that they consider objectionable. ${ }^{73}$ While major OTT players Netflix, Hotstar, Jio, Voot, Zee5, SonyLIV, ALTBalaji, and Eros Now felt obliged in 2019 to sign a self-censorship code, which would block content considered disrespectful to national symbols and religions, ${ }^{74}$ direct regulatory action appears tempered by the fact that OTT platforms, including Google, Amazon, and Netflix, have "cultivat[ed] ties with established media industries and their talent and labour infrastructures."75 The size of the companies, the scale of the local audiovisual production, and the regulatory capacity of the Indian state mark this current period as distinct from the early 1990s.

For its part, the Telecoms Regulatory Authority of India has primarily expressed concerns over security, cultural sensitives, and disturbances to the country's "social fabric" caused by content carried by international OTT communication services such as Snapchat and WhatsApp. ${ }^{76}$ Its concerns about OTT video content libraries appear to be relatively muted and its prime interventions to date have been in prohibiting Facebook's Free Basics zerorating initiative in 2016 and subsequently issuing net neutrality recommendations which were accepted by India's Telecom Commission in July 2018. These net neutrality regulations, while banning "any form of discrimination or interference" with data, ${ }^{77}$ exempt content delivery networks (CDNs) that allow integrated "hyper-giants" to deliver content within their 
network using high-speed connections. ${ }^{78}$ While Netflix has peering CDN relationships in India, the new regulations are particularly beneficial to large network operators such as Reliance Jio and Bharti Airtel. ${ }^{79}$

Athique has argued that the increasing integration of the global digital economy requires us to think critically once more about media imperialism (control over the media apparatus) and cultural imperialism (the influence of foreign content in particular markets). ${ }^{80}$ Athique argues that the geopolitics of information in the digital era are primarily centered on control over the data infrastructure and data harvest, rather than control over content and message. He avers that imperialism is not simply implied by a transnational presence, but has to emerge from a strategic intent to enter and dominate media markets. Aouragh and Chakravartty have argued that the Indian Prime Minister Narendra Modi's visit to Silicon Valley in 2015, promoting the "Digital India" program, represented "the US imprint on 21st century technology" and the "infrastructures of empire." Contrary to Athique, Aouragh and Chakravartty have sought to collapse the distinction between "the material stuff of cables and wires" and "the 'soft' and more amorphous networks of cultural exchange shaped by European (and American) colonial power." 81

However, in the case of OTT, collapsing the distinction between "middle and top layers of the internet" and "the hardware, or material infrastructure" 82 may well impede a full analysis of the different roles of US-based internet giants and large Indian corporate interests and the "contradictions of the postcolonial nation state" itself. ${ }^{83}$ That is, the OTT sector's development needs to be understood in relation to interrelated, yet still discernible, interests at the internet's top layers (including US and Indian-based OTT players) and at the level of material infrastructure. ${ }^{84}$ This has to be the case because "platformization" will inevitably "alter market structures, affect competitive strategies and change the rules of the "rules of the game', but its impact also has to be mediated by power structures and institutional relationships that have been persistent for decades." 85

As the "National Digital Communications Policy, 2018" (and the broader "Digital India" initiative) demonstrates, telecommunications remains "a key project of techno-nationalism that a postcolonial nation-state wants to control and champion." 86 The interests of TSP and infrastructure providers figure centrally in these plans. Although India may appear to be out of step with renewed concerns around the cultural effects of platform imperialism, the recently drafted Indian National e-Commerce Policy 2019 clearly emphasizes Indian data localization and storage. Reliance Jio's Mukesh Ambani has also decried the "data colonization" of foreign firms. ${ }^{87}$ Yet, given that Jio has extended its commercial partnerships with Netflix and other OTT providers, it appears that these concerns about data relate to the ownership and development of infrastructure rather than "cultural imperialism" in terms of content.

In the recent evolution of the Indian media economy, we have seen the consolidation of television via the digitalization process along with the consolidation of film via the digitalization of its distribution and exhibition infrastructures. ${ }^{88}$ In the telecom sectors, Hill and Athique have shown how consolidation of the market was driven by local capital concentrations and their preferable access to foreign investment, tax loopholes, and technology transfers. ${ }^{89}$ Similarly, at both the national and global levels, the OTT sector is dominated by a small number of players capable of bearing the infrastructure costs and absorbing the losses required 
to build up audiences and market share. Yet in seeking to "establish the supremacy of the market," ${ }^{90}$ Indian state regulators have maintained significant regulatory power to act as a "network builder" in an increasingly privatized telecom sector. ${ }^{11}$ Unlike telecoms, however, the OTT sector brings media content back into the frame and thereby becomes illustrative of both media and cultural imperialism via its convergence of content archives and telecom infrastructure.

Although the projected shift toward subscription-based business models implies that the global players will become more and more active in the business of content, this central characteristic of the more mature US market is not yet evident in India. ${ }^{92}$ Nevertheless, it is by no means assured that the country will necessarily "develop its own unique business models rather than adopt global ones" for processes of vertical integration, present in the US case, are clearly evident. ${ }^{93}$ Correspondingly, as opposed to more sanguine interpretations that offset media globalization with localized forms of user-generated content, it seems clear that there are multiple issues for TRAI to consider in developing a comprehensive policy approach. To what extent should the major holders of digital distribution infrastructure be allowed to dominate the production and retail sectors for audiovisual content? To what extent should the reliance of the Government of India on TSPs in developing the infrastructure of Digital India be allowed to predetermine the market share for digital content? How should international partnerships in telecom infrastructure be situated in regard to longstanding provisions for cultural diversity? Should established Indian content providers be safeguarded in the face of competition from telecom giants and global platforms? Who should underwrite the costs of online video in a context where demand for digital services is perpetually outstripping network capacity? It is these manifold issues surrounding market power, both internally and internationally, that effectively put the issue of media imperialism back on the table, even as facts on the ground emerge faster than any policy consensus.

${ }^{1}$ Scott W. Fitzgerald is a senior lecturer in the Curtin Business School, Curtin University, Perth, Australia. His research interests cover cultural industry corporations, creative work, public services (especially education), and new public management. He would like to thank this special section's editor, Adrian Athique, and the anonymous referee for their detailed and insightful comments on earlier versions of this paper.

${ }^{2}$ See, for example, Dal Yong Jin, "Digital Platform as a Double-Edged Sword: How to Interpret Cultural Flows in the Platform Era," International Journal of Communication 11 (2017): 3880-98; Dal Yong Jin, "The Construction of Platform Imperialism in the Globalisation Era," in Marx in the Age of Digital Capitalism, ed. Christian Fuchs and Vincent Mosco (Leiden: Brill, 2016), 322-49; Dal Yong Jin, Digital Platforms, Imperialism and Political Culture (NY: Routledge, 2015). Compare Jin's approach to Dan Schiller and ShinJoung Yeo, "Science and Engineering in Digital Capitalism," in Routledge Handbook of the Political Economy of Science, ed. David Tyfield, Rebecca Lave, Samuel Randalls, and Charles Thorpe (Abingdon: Routledge, 2017), 70-82, and Dwayne Winseck, "The Geopolitical Economy of the Global Internet Infrastructure," Journal of Information Policy 7 (2017): 228-67. 
${ }^{3}$ Nyay Bhushan, "Why India Will Be a Key Battleground for Amazon and Netflix," The Hollywood Reporter, December 16, 2016. https://www.hollywoodreporter.com/ news /why-india-will-be-a-key-battleground-amazon-netflix-956038

${ }^{4}$ Ibid.

${ }^{5}$ See the analysis in Deloitte, Economic Contribution of the Film and Television Industry in India, 2017 (Mumbai: Deloitte Touche Tohmatsu India LLP, 2018); Deloitte, Technology, Media and Telecommunications Predictions 2018, India ed. (Mumbai: Deloitte Touche Tohmatsu India LLP, 2018); Federation of Indian Chambers of Commerce and Industry-Ernst \& Young, Re-imagining India's MEE Sector (New Delhi: Federation of Indian Chambers of Commerce and Industry, 2018); Mudra Institute of Communications, Ahmedabad, Indian OTT Platforms Report 2018 (Ahmedabad: Mudra Institute of Communications, Ahmedabad, 2018).

${ }^{6}$ See the discussion in Scott Fitzgerald, "Structure of the Cultural Industries: Global Corporation to SMEs," in The Routledge Companion to the Cultural Industries, ed. Kate Oakley and Justin O'Connor (London: Routledge, 2015), 70-85.

${ }^{7}$ See, for example, Alex Bruns, Blogs, Wikipedia, Second Life, and Beyond: From Production to Produsage (NY: Peter Lang, 2008); Mark Deuze, "Convergence Culture in the Creative Industries," International Journal of Cultural Studies 10(2, 2007): 243-63; Dan Hunter, Ramon Lobato, Megan Richardson, and Julian Thomas, Amateur Media: Social, Cultural and Legal Perspectives (NY: Routledge, 2013).

${ }^{8}$ Stuart Cunningham and David Craig, "Online Entertainment: A New Wave of Media Globalization?," International Journal of Communication 10 (2016): 5409-25; Stuart Cunningham, Terry Flew, and Adam Swift, Media Economics (London: Palgrave Macmillan, 2015), 148.

${ }^{9}$ David Hesmondhalgh, "Why It Matters When Big Tech Firms Extend Their Power into Media Content," The Conversation, November 15, 2017, https://theconversa tion.com/why-it-matters-when-big-tech-firms-extend-their-power-into-me dia-content-86876.

${ }^{10}$ Hesmondhalgh, "Why It Matters When Big Tech Firms Extend Their Power into Media Content."

${ }^{11}$ Matthew Garrahan, "Netflix Launches in 130 Countries amid Online Streaming Battle with Amazon," Financial Times, January 7, 2016, https://search.proquest.com/doc view/1762863152?accountid=10382. For an extended analysis of Netflix's development, see Ramon Lobato, Netflix Nations: The Geography of Digital Distribution (NY: New York University Press, 2019).

${ }^{12}$ Shalini Ramachandran, "Amazon Video to Go Global," The Wall Street Journal, November 18, 2016, p. B2 ; "Netflix: Debtmogorgon," Financial Times, October 17, 2017; Todd Spangler, "Netflix Original Content Outscores HBO, Hulu, Amazon on Customer-Satisfaction Survey," Variety, February 21, 2019.

${ }^{13}$ Rebecca Keegan, "How Amazon's Film Plans Differ from Netflix (and All the Rest)," The Hollywood Reporter, February 19, 2019.

14 Todd Spangler, "Netflix Targeting $50 \%$ of Content to Be Original Programming, CFO Says," Variety, September 20, 2016; Spangler, "Netflix Original Content Outscores HBO, Hulu, Amazon on Customer-Satisfaction Survey"; Aaron Hemsworth, "Netflix Battles Competition through Huge Investments," Market Realist, November 7, 2017; 
Tim Bradshaw and Shannon Bond, "Netflix Looks to become World's Entertainer as It Hits Milestone," Financial Times, July 20, 2017.

${ }^{15}$ Georg Szalai, "Disney, Comcast to Dominate Global Content Spending, Study Says," The Hollywood Reporter, December 10, 2018.

16 Tripp Mickle, "Apple Builds \$1 Billion Hollywood War Chest," The Wall Street Journal, August 17, 2017; Jack Nicas, "YouTube's Focus Is Being a Platform, Not Producing Premium Content, CEO Says," The Wall Street Journal, October 26, 2016, https://search-proquest-com.dbgw.lis.curtin.edu.au/docview/2195365939?acco untid=10382; Deepa Seetharaman, "Facebook Embraces 'Video-First' Future," The Wall Street Journal, September 9, 2017.

${ }^{17}$ Natalie Jarvey, "YouTube to Pull Back on Scripted in 2020 amid Ad-Supported Push." The Hollywood Reporter, November 27, 2018; Todd Spangler, "YouTube to Make New Originals Available for Free, Ad-Supported Viewing with 'Single Slate' Strategy," Variety, November 27, 2018.

${ }^{18}$ Amanda Lotz, Portals: A Treatise on Internet-Distributed Television (Ann Arbor: University of Michigan, 2017), 10.

19 Todd Spangler, "Netflix Stock Shoots to Record Highs as Investors Embrace CashBurn Strategy," Variety, July 18, 2017. For an insightful discussion of processes of financialisation see Philippe Bouquillion, "Concentration, financiarisation et relations entre les industries de la culture et industries de la communication," [Concentration, financialization and relations between the cultural industries and the communication industries] Revue française des sciences de l'information et de la communication, published electronically September 1, 2012: 1-10, doi:10.4000/rfsic.94.

20 "Netflix: Debtmogorgon."

${ }^{21}$ Anna Akins and Waqar Jamshed, "Analysis: Big Tech No Longer Certain Bet in 2019," SNL Kagan Media E Communications Report, January 9, 2019; Macrotrends, "Internet Services: Top Stocks," 2019, https://www.macrotrends.net/stocks/research (accessed June 18, 2019); Richard Waters, Hannah Kuchler, and Shannon Bond, "Silicon Valley: Big Tech prepares for its second act," Financial Times, August 4, 2018.

${ }^{22}$ Lotz, Portals, 13.

23 Ibid.

${ }^{24}$ Bernard Miège, "The Logics at Work in the New Cultural Industries," Media, Culture $\mathcal{E}$ Society 9 (3, 1987): 273-89; Bernard Miège, "Cultural and Creative Industries and the Political Economy of Communication," in Making Media, ed. Mark Deuze and Mirijam Prenger (Amsterdam: Amsterdam University Press, 2019), 73-84. See also Patrice Flichy, Les Industries De L'imaginaire [The Industries of the Imagination] (Grenoble: Presses universitaires de Grenoble, 1980); Jean-Guy Lacroix and Gaetan Tremblay, "The 'Information Society' and Cultural Industries Theory," Current Sociology 45 (4, 1997): 1-162; Nicholas Garnham, Emancipation, the Media, and Modernity (Oxford: Oxford University Press, 2000); Aphra Kerr, Global Games (London: Routledge, 2017).

${ }^{25}$ For a fuller discussion of logics in the cultural industries, see Scott Fitzgerald, Corporations and Cultural Industries: Time Warner, Bertelsmann, and News Corporation (NY: Rowman \& Littlefield, 2012), 72-92.

${ }^{26}$ Garnham, Emancipation, the Media, and Modernity, 53. See also the discussion of "flow" in Raymond Williams, Television (London: Routledge, 1990). 
${ }^{27}$ Lacroix and Tremblay, "The 'Information Society' and Cultural Industries Theory," 63; Lotz, Portals, 29.

${ }^{28}$ Sangeet Kumar, "YouTube Nation: Precarity and Agency in India's Online Video Scene," International Journal of Communication 10 (2016): 5608-25.

29 "The YouTube Onslaught," The Pioneer, November 18, 2012; Vibodh Parthasarathi and Alam Srinivas, Mapping Digital Media: India (London: Open Society Foundations, 2012); Federation of Indian Chambers of Commerce and Industry-KPMG, The Stage Is Set: Indian Media and Entertainment Industry Report, 2014 (Delhi: Federation of Indian Chambers of Commerce and Industry, 2014).

${ }^{30}$ Raja Simhan, "YouTube Eyes Regional Flavour," Business Line, October 18, 2012.

${ }^{31}$ Collin Furtado, "TV Broadcasters Vie for Piece of the Rs 4,600 Crore Digital VoD Market Pie." Exchange4media.com, November 20, 2015.

32 "Zees Ditto TV Eyes Doubling Revenue to Rs 60 Cr This Fiscal," India Today, October 18, 2015; "Sony to Move Its Video Streaming Service Sony LIV to a Fee-Based Model," The Economic Times, August 31, 2015; Shuchi Bansal, "Indian Media Industry Likely to Touch Rs 2.26 Trillion by 2020," Live Mint, March 31, 2016; Simran Sabherwal and Allan Dsouza, "OTT: AVoD vs SVoD," Impact 48 (2017). https://www.impactonnet .com/impact-feature/ott-avod-vs-svod-5300.html.

${ }^{33}$ Federation of Indian Chambers of Commerce and Industry-KPMG, Media for the Masses: Indian Media and Entertainment Industry Report (Delhi: Federation of Indian Chambers of Commerce and Industry, 2017), 29.

${ }^{34}$ Sabherwal and Dsouza, "OTT: AVoD vs SVoD."

${ }^{35}$ Karan Kashyap, "Streaming Kings like Amazon \& Netflix Are Going Niche to Win India's Highly Competitive OTT Race," Forbes, September 11, 2017.

${ }^{36}$ Colin Agur, "A Foreign Field No Longer: India, the IPL, and the Global Business of Cricket," Journal of Asian and African Studies 48 (5, 2013): 541-56; Amit Gupta, "The IPL and the Indian Domination of Global Cricket," Sport in Society 14 (10, 2011): 1316-25.

${ }^{37}$ Kashyap, "Streaming Kings like Amazon \& Netflix Are Going Niche to Win India's Highly Competitive OTT Race"; Naman Ramachandran, "Netflix, Amazon Take Divergent Paths to Reach Indian Audience," The Wall Street Journal, November 1, 2016; Simon Mundy, "Netflix to Make First Original Series in India," Financial Times, June 6, 2016. Simon Mundy, "Amazon and Netflix Study India's Rule Book," Financial Times, September 9, 2017.

${ }^{38}$ Federation of Indian Chambers of Commerce and Industry-KPMG, Media for the Masses, 35-36.

${ }^{39}$ Federation of Indian Chambers of Commerce and Industry-KPMG, Media for the Masses, i.

${ }^{40}$ Federation of Indian Chambers of Commerce and Industry-KPMG, Media for the Masses, 35-36.

${ }^{41}$ Federation of Indian Chambers of Commerce and Industry-KPMG, Media for the Masses.

42 Elizabeth Evans, Paul McDonald, Juyeon Bae, Sriparna Ray, and Emanuelle Santos, "Universal Ideals in Local Realities: Online Viewing in South Korea, Brazil and India," Convergence 22 (4, 2016): 408-25. 
${ }^{43}$ Telecom Regulatory Authority of India, The Indian Telecom Services Performance Indicators -January-March, 2017 (New Delhi: Telecom Regulatory Authority of India, 2017).

${ }^{44}$ Manjunath Pendakur, "Twisting and Turning: India's Telecommunications and Media Industries under the Neoliberal Regime," International Journal of Media \& Cultural Politics 9 (2, 2013): 107-31.

${ }^{45}$ Vibodh Parthasarathi, Arshad Amanullah, and Susan Koshy, "Digitalization as Formalization: A View from Below," International Journal of Digital Television 7 (2, 2016): $155-71$.

${ }^{46}$ Federation of Indian Chambers of Commerce and Industry-Ernst \& Young, Re-imagining India's MEE Sector.

${ }^{47}$ Evans et al., "Universal Ideals in Local Realities," 412.

${ }^{48}$ Federation of Indian Chambers of Commerce and Industry-KPMG, Media for the Masses.

${ }^{49}$ Federation of Indian Chambers of Commerce and Industry-KPMG, Media for the Masses, 31.

${ }^{50}$ Federation of Indian Chambers of Commerce and Industry-KPMG, The Future: Now Streaming-Indian Media and Entertainment Industry Report (Delhi: Federation of Indian Chambers of Commerce and Industry, 2016), 30; Federation of Indian Chambers of Commerce and Industry-KPMG, Media for the Masses, $\mathrm{x}$.

${ }^{51}$ Hanish Bhatia, "Netflix Restricted to Premium Subscribers, Hotstar Leads Indian OTT Content Market," The Economic Times, January 5, 2018; Nyay Bhushan, "Study: Indians Prefer Free Digital Content over Paid Services Like Netflix, Amazon," The Hollywood Reporter, October 18, 2018; Kriti Gupta, "India's Sharing Culture Hurts Online Streaming Platforms, 8 out of 10 People Use Others' Login," India Times, September 21, 2018.

${ }^{52}$ Sabherwal and Dsouza, "OTT: AVoD vs SVoD"; Federation of Indian Chambers of Commerce and Industry-Ernst \& Young, Re-imagining India's MEE Sector; KPMG, Media Ecosystems: The Walls Fall Down (New Delhi: KPMG, 2018).

${ }^{53}$ Federation of Indian Chambers of Commerce and Industry-KPMG, Media for the Masses, 37.

54 "Sony to Move Its Video Streaming Service Sony LIV to a Fee-Based Model." https:// tech.economictimes.indiatimes.com/news/internet/sony-to-move-its-videostreaming-service-sony-liv-to-a-fee-based-model/48739192

${ }^{55}$ Sabherwal and Dsouza, "OTT: AVoD vs SVoD." https://www.impactonnet.com/ impact-feature/ott-avod-vs-svod-5300.html.

${ }^{56}$ Exchange4media Staff, "Subscription and Advertising Might Be the Answer to OTT's Monetisation Problem," Exchange4Media.com, May 23, 2017. https:// www.exchange 4media.com/digital-news/subscription-and-advertising-mightbe-the-answer-to-ott's-monetisation-problem-68915.html

${ }^{57}$ Todd Spangler, "Police Make Arrests in 'Game of Thrones' Piracy Case in India," Variety, August 14, 2017.

${ }^{58}$ Sabherwal and Dsouza, "OTT: AVoD vs SVoD"; Ernst \& Young, Digital Opportunity: Indian Media and Entertainment 2017 (Delhi: Ernst \& Young, 2017).

${ }^{59}$ Sabherwal and Dsouza, "OTT: AVoD vs SVoD." 
${ }^{60}$ Federation of Indian Chambers of Commerce and Industry-KPMG, Media for the Masses, 46.

${ }^{61}$ Sabherwal and Dsouza, "OTT: AVoD vs SVoD."

${ }^{62}$ Federation of Indian Chambers of Commerce and Industry-KPMG, Media for the Masses, 46.

${ }^{63}$ Federation of Indian Chambers of Commerce and Industry-KPMG, Media for the Masses, 67; for discussion of Reliance Industries Limited push into the Indian media sector, see Paranjoy Guha Thakurta and Subi Chaturvedi, "Corporatisation of the Media: Implications of the RIL-Network18-Eenadu Deal," Economic \& Political Weekly 47 (7, 2012): 10-13; Paranjoy Guha Thakurta, "What Future for the Media in India?," Economic \& Political Weekly 49 (24, 2014). https://search-proquest-com .dbgw.lis.curtin.edu.au/docview/2153723638?accountid=10382

${ }^{64}$ Colin Agur, "Re-imagining the Indian State: External Forces and the Transformation of Telecommunications Policy, 1947-Present," Global Media and Communication 14 (1, 2018): 65-83; Rahul Mukherjee, "Jio Sparks Disruption 2.0: Infrastructural Imaginaries and Platform Ecosystems in 'Digital India," Media, Culture \& Society 41 (2, March 2019): 175-95; Rahul Mukherji, "The Politics of Telecommunications Regulation: State-Industry Alliance Favouring Foreign Investment in India," The Journal of Development Studies 44 (10, 2008): 1405-23; Pendakur, "Twisting and Turning"; Paranjoy Guha Thakurta and Aditi Roy Ghatak, "The Immaculate Conception of Reliance Jio," The Wire, March 6, 2016.

${ }^{65}$ Ernst \& Young, Digital Opportunity, 36.

${ }^{66}$ Nyay Bhushan, "Indian Film Company Eros in Talks to Sell Library to Apple, Netflix, Amazon," The Hollywood Reporter, August 8, 2017.

${ }^{67}$ Patrick Frater, "Mukesh Ambani's Reliance Industries Takes Stake in Eros International," Variety, February 20, 2018; Naman Ramachandran, "Reliance Industries Spends \$712 Million on Cable and Broadband Acquisitions," Variety, October 19, 2018; Gaurav Laghate, "Reliance to Buy Majority Stakes in Den Networks, Hathway Cable for Rs 5,230 Crore," The Economic Times, October 18, 2018.

${ }^{68}$ Jin, "The Construction of Platform Imperialism in the Globalisation Era."

${ }^{69}$ Cunningham and Craig, "Online Entertainment."

${ }^{70}$ Aswin Punathambekar and Sriram Mohan, "Digital Platforms, Globalization and Culture," in Media and Society, ed. James Curran and David Hesmondhalgh (London: Bloomsbury, 2019), 208.

${ }^{71}$ Vikram Aditya Narayan and Raka Arya, "Regulation of New Media: The Indian Scenario," in India Connected: Mapping the Impact New Media, ed. Sunetra Sen Narayan and Shalini Narayanan (Sherman Oaks, CA: SAGE, 2016), 152.

${ }^{72}$ Pradip Ninan Thomas, "Infrastructure and Platform Anxieties in India," in Digital transactions in Asia, ed. Adrian Athique and Emma Baulch (NY: Routledge, 2019), 44-62.

${ }^{73}$ Japreet Grewal, "Netflix: Is the Film Censorship Law There Yet?," CyFy Journal 3 (2016): 73, 75. In December 2018, the Government called for public submissions on a proposed amendment to the IT Act ("The Information Technology [Intermediary Guidelines (Amendment) Rules] 2018) that would address the "misuse of social media platforms and spreading of fake news". Submissions closed in January 2019. 
${ }^{74}$ Naman Ramachandran, "Netflix and Amazon Take Different Sides on Content Regulation in India," Variety, January 17, 2019.

${ }^{75}$ Punathambekar and Mohan, "Digital Platforms, Globalization and Culture," 216.

76 Telecom Regulatory Authority of India, Consultation Paper on Regulatory Framework for Over-the-Top (OTT) Services (New Delhi: Telecom Regulatory Authority of India, 2015).

77 Telecom Regulatory Authority of India, The Indian Telecom Services Performance Indicators -January-March 2017.

${ }^{78}$ Lobato, Netflix Nations, 98.

${ }^{79}$ Kalyan Parbat, "Telcos Slam TRAI Views on Net Neutrality, Term Move to Set up a Monitoring Body 'Draconian,"' The Economic Times, November 29, 2017.

${ }^{80}$ Adrian Athique, Transnational Audiences (Cambridge: Polity Press, 2016).

${ }^{81}$ Miriyam Aouragh and Paula Chakravartty, "Infrastructures of Empire: Towards a Critical Geopolitics of Media and Information Studies," Media, Culture E Society 38 $(4,2016), 559-75$; Compare with Boyd-Barret's argument that media imperialism involves more than content but also "the technological, administrative and business infrastructures that enable the production and dissemination of point-ofconsumption content, including the range of devices through which that content is produced, delivered and received": Oliver Boyd-Barret, Media Imperialism (London: SAGE, 2015), 4.

${ }^{82}$ Dwayne Winseck, "The Geopolitical Economy of the Global Internet Infrastructure," Journal of Information Policy 7 (2017): 228-67.

${ }^{83}$ Aouragh and Chakravartty, "Infrastructures of Empire," 562.

${ }^{84}$ Martin Fransman, Models of Innovation in Global ICT Firms: The Emerging Global Innovation Ecosystems, JRC Scientific and Policy Reports-EUR 26774 EN (Seville: Joint Research Center-Institute for Prospective Technological Studies, 2014).

${ }^{85}$ Tom Evens and Karen Donders, Platform Power and Policy in Transforming Television Markets (Cham: Palgrave Macmillan, 2018), 3.

${ }^{86}$ Mukherjee, "Jio Sparks Disruption 2.0," 182.

${ }^{87}$ Simon Mundy, "Reliance to Take on Amazon and Flipkart in Indian Ecommerce," Financial Times, January 18, 2019.

${ }^{88}$ Adrian Athique, Vibodh Parthasarathi, and S. V. Srinivas, eds., The Indian Media Economy. Vol. 1: Industrial Dynamics and Cultural Adaptation (New Delhi: Oxford University Press, 2018). Adrian Athique, Vibodh Parthasarathi, and S. V. Srinivas, eds., The Indian Media Economy. Vol. 2: Market Dynamics and Social Transactions (New Delhi: Oxford University Press, 2018); Parthasarathi, Amanullah, and Koshy, "Digitalization as Formalization."

${ }^{89}$ Douglas Hill and Adrian Athique, "The Role of off Shore Financial Centres in Indian Telecoms," in The Indian Media Economy. Vol. 1: Industrial Dynamics and Cultural Adaptation, ed. Adrian Athique, Vibodh Parthasarathi, and S. V. Srinivas (New Delhi: Oxford University Press, 2018), 66-92.

${ }^{90}$ Pendakur, "Twisting and Turning."

${ }^{91}$ Agur, "Re-Imagining the Indian State," 16.

${ }^{92}$ See Lobato, Netflix Nations, Ishita Tiwary, "Amazon Prime Video and the Indian Media Market: A Platform Ecosphere," Media Industries Journal (2019).

${ }^{93}$ Federation of Indian Chambers of Commerce and Industry-KPMG, The Future, ii. 


\section{Bibliography}

Agur, Colin. "A Foreign Field No Longer: India, the IPL, and the Global Business of Cricket." Journal of Asian and African Studies 48, no. 5 (2013): 541-56.

Agur, Colin. "Re-Imagining the Indian State: External Forces and the Transformation of Telecommunications Policy, 1947-Present." Global Media and Communication 14, no. 1 (2018): 65-83. doi:10.1177/1742766518759794.

Akins, Anna, and Waqar Jamshed. "Analysis: Big Tech No Longer Certain Bet in 2019." SNL Kagan Media \& Communications Report, January 9, 2019.

Aouragh, Miriyam, and Paula Chakravartty. "Infrastructures of Empire: Towards a Critical Geopolitics of Media and Information Studies." Media, Culture \& Society 38, no. 4 (2016): 559-75. doi:10.1177/0163443716643007.

Athique, Adrian. Transnational Audiences. Cambridge: Polity Press, 2016.

Athique, Adrian, Vibodh Parthasarathi, and S. V. Srinivas, eds. The Indian Media Economy. Vol. 1: Industrial Dynamics and Cultural Adaptation. New Delhi: Oxford University Press, 2018.

Athique, Adrian, Vibodh Parthasarathi, and S. V. Srinivas, eds. The Indian Media Economy. Vol. 2: Market Dynamics and Social Transactions. New Delhi: Oxford University Press, 2018.

Bansal, Shuchi. "Indian Media Industry Likely to Touch Rs 2.26 Trillion by 2020." Live Mint, March 31, 2016.

Bhatia, Hanish. "Netflix Restricted to Premium Subscribers, Hotstar Leads Indian OTT Content Market." The Economic Times, January 5, 2018.

Bhatia, Rahul. "The inside Story of Facebook's Biggest Setback." The Guardian, May 12, 2016.

Bhushan, Nyay. "Indian Film Company Eros in Talks to Sell Library to Apple, Netflix, Amazon." The Hollywood Reporter, August 8, 2017.

Bhushan, Nyay. "Study: Indians Prefer Free Digital Content over Paid Services Like Netflix, Amazon." The Hollywood Reporter, October 18, 2018.

Bhushan, Nyay. "Why India Will Be a Key Battleground for Amazon and Netflix." The Hollywood Reporter, December 16, 2016.

Bouquillion, Philippe. "Concentration, financiarisation et relations entre les industries de la culture et industries de la communication." Revue française des sciences de l'information et de la communication. [Concentration, financialization and relations between the cultural industries and the communication industries] Published Electronically September 1, 2012:1-10 doi:10.4000/rfsic.94.

Boyd-Barrett, Oliver. Media Imperialism. London: SAGE, 2015.

Bradshaw, Tim, and Shannon Bond. "Netflix Looks to become World's Entertainer as It Hits Milestone." Financial Times, July 20, 2017.

Bruns, Alex. Blogs, Wikipedia, Second Life, and Beyond: From Production to Produsage. New York: Peter Lang, 2008. 
comScore. "Online Video Consumption in India Has Doubled in the Past 2 Years." Mumbai, 2013. https://www.comscore.com/Insights/Press-Releases/2013/5/Online-VideoConsumption-in-India-May-2013.

Cunningham, Stuart, and David Craig. "Online Entertainment: A New Wave of Media Globalization?" International Journal of Communication 10 (2016): 5409-25.

Cunningham, Stuart, Terry Flew, and Adam Swift. Media Economics. London: Palgrave Macmillan, 2015.

Deloitte. Economic Contribution of the Film and Television Industry in India 2017. Mumbai: Deloitte Touche Tohmatsu India LLP, 2018a.

Deloitte. Technology, Media and Telecommunications Predictions 2018. India ed. Mumbai: Deloitte Touche Tohmatsu India LLP, 2018b.

Deuze, Mark. "Convergence Culture in the Creative Industries." International Journal of Cultural Studies 10, no. 2 (2007): 243-63.

Eisen, Ben. "Traders Jump into Fang Futures on First Day." The Wall Street Journal, November 9, 2017, p. B11.

Ernst \& Young. Digital Opportunity: Indian Media and Entertainment 2017. Delhi: Ernst \& Young, 2017.

Evans, Elizabeth, Paul McDonald, Juyeon Bae, Sriparna Ray, and Emanuelle Santos. "Universal Ideals in Local Realities: Online Viewing in South Korea, Brazil and India." Convergence 22, no. 4 (2016): 408-25. doi:10.1177/1354856516641629.

Evens, Tom, and Karen Donders. Platform Power and Policy in Transforming Television Markets. Cham: Palgrave Macmillan, 2018.

Exchange4media Staff. "Subscription and Advertising Might Be the Answer to OTT's Monetisation Problem." Exchange4Media.com, May 23, 2017.

Federation of Indian Chambers of Commerce and Industry/Ernst \& Young. Re-imagining India's MEE Sector. New Delhi: Federation of Indian Chambers of Commerce and Industry, 2018.

Federation of Indian Chambers of Commerce and Industry-KPMG. Media for the Masses: Indian Media and Entertainment Industry Report 2017. New Delhi: Federation of Indian Chambers of Commerce and Industry, 2017.

Federation of Indian Chambers of Commerce and Industry-KPMG. The Future: Now Streaming-Indian Media and Entertainment Industry Report 2016. New Delhi: Federation of Indian Chambers of Commerce and Industry, 2016.

Federation of Indian Chambers of Commerce and Industry-KPMG. The Stage Is Set: Indian Media and Entertainment Industry Report, 2014. New Delhi: Federation of Indian Chambers of Commerce and Industry, 2014.

Financial Times. "Netflix: Debtmogorgon." October 17, 2017.

Fitzgerald, Scott W. Corporations and Cultural Industries: Time Warner, Bertelsmann, and News Corporation. New York: Rowman \& Littlefield, 2012. 
Fitzgerald, Scott W. "The Structure of the Cultural Industries: Global Corporations to SMEs." In The Routledge Companion to the Cultural Industries, edited by K. Oakley and J. O'Connor, 70-86. London: Routledge, 2015.

Flichy, Patrice. Les Industries De L'imaginaire. [The Industries of the Imagination] Grenoble: Presses universitaires de Grenoble, 1980.

Fransman, Martin. Models of Innovation in Global ICT Firms: The Emerging Global Innovation Ecosystems. JRC Scientific and Policy Reports-EUR 26774 EN. Seville: Joint Research Centre-Institute for Prospective Technological Studies, 2014.

Frater, Patrick. "Mukesh Ambani's Reliance Industries Takes Stake in Eros International." Variety, February 20, 2018. https://variety.com/2018/biz/asia/mukesh-ambanireliance-industries-take-eros-1202704828/.

Furtado, Collin. "TV Broadcasters Vie for Piece of the Rs 4,600 Crore Digital VoD Market Pie." Exchange4media, November 20, 2015. http://www.exchange4media.com/ TV/TV-broadcasters-vie-for-piece-of-the-Rs-4600-crore-digital-VoD-marketpie_62412.html.

Garnham, Nicholas. Emancipation, the Media, and Modernity: Arguments about the Media and Social Theory. Oxford: Oxford University Press, 2000.

Garrahan, Matthew. "Netflix Launches in 130 Countries amid Online Streaming Battle with Amazon." Financial Times, January 7, 2016.

Grewal, Japreet. "Netflix: Is the Film Censorship Law There Yet?" CyFy Journal 3 (2016): $72-91$.

Gupta, Amit. "The IPL and the Indian Domination of Global Cricket." Sport in Society 14, no. 10 (2011): 1316-25.

Gupta, Kriti. "India's Sharing Culture Hurts Online Streaming Platforms, 8 out of 10 People Use Others' Login." India Times, September 21, 2018.

Hemsworth, Aaron. "Netflix Battles Competition through Huge Investments." Market Realist, November 7, 2017. https://marketrealist.com/2017/11/netflix-battles-competitionhuge-investment/.

Hesmondhalgh, David. "Why It Matters When Big Tech Firms Extend Their Power into Media Content." The Conversation, November 15, 2017. https://theconversation.com/whyit-matters-when-big-tech-firms-extend-their-power-into-media-content-86876.

Hill, Douglas, and Adrian Athique. "The Role of off Shore Financial Centres in Indian Telecoms." In The Indian Media Economy. Vol. 1: Industrial Dynamics and Cultural Adaptation, edited by Adrian Athique, Vibodh Parthasarathi, and S. V. Srinivas, 66-92. New Delhi: Oxford University Press, 2017.

Hunter, Dan, Ramon Lobato, Megan Richardson, and Julian Thomas. Amateur Media: Social, Cultural and Legal Perspectives. New York: Routledge, 2013.

India Today. "Zees Ditto TV Eyes Doubling Revenue to Rs $60 \mathrm{Cr}$ This Fiscal." October 18, 2015. http://indiatoday.intoday.in/story/zees-ditto-tv-eyes-doubling-revenue-tors-60-cr-this-fiscal/1/501590.html. 
Jarvey, Natalie. "YouTube to Pull Back on Scripted in 2020 Amid Ad-Supported Push." The Hollywood Reporter, November 27, 2018.

Jin, Dal Yong. "Digital Platform as a Double-Edged Sword: How to Interpret Cultural Flows in the Platform Era." International Journal of Communication 11 (2017): 3880-98.

Jin, Dal Yong. Digital Platforms, Imperialism and Political Culture: Routledge New Developments in Communication and Society. New York: Routledge, 2015.

Jin, Dal Yong. "The Construction of Platform Imperialism in the Globalisation Era." In Marx in the Age of Digital Capitalism, edited by Christian Fuchs and Vincent Mosco, 322-49. Leiden: Brill, 2016.

Kashyap, Karan. "Streaming Kings like Amazon \& Netflix Are Going Niche to Win India's Highly Competitive OTT Race." Forbes, September 11, 2017. https://www.forbes.com/sites / krnkashyap/2017/09/11/streaming-kings-like-amazon-netflix-are-going-nicheto-win-indias-highly-competitive-ott-race/\#3c841aae1672.

Keegan, Rebecca. "How Amazon's Film Plans Differ from Netflix (and All the Rest)." The Hollywood Reporter, February 19, 2019.

Kerr, Aphra. Global Games: Production, Circulation and Policy in the Networked Era. London: Routledge, 2017.

KPMG. Media Ecosystems: The Walls Fall Down. New Delhi: KPMG, 2018.

Kumar, Sangeet. "YouTube Nation: Precarity and Agency in India's Online Video Scene." International Journal of Communication 10 (2016): 5608-25.

Lacroix, Jean-Guy, and Gaetan Tremblay. "The 'Information Society' and Cultural Industries Theory." Current Sociology 48, no. 4 (1997): 1-162.

Laghate, Gaurav. "Reliance to Buy Majority Stakes in Den Networks, Hathway Cable for Rs 5,230 Crore." The Economic Times, October 18, 2018. https://economictimes .indiatimes.com/markets/stocks/news/reliance-to-buy-majority-stakes-in-dennetworks-hathway-cable-for-rs-5230-crore/articleshow/66263846.cms.

Lobato, Ramon. Netflix Nations: The Geography of Digital Distribution. New York: New York University Press, 2019.

Lotz, Amanda. Portals: A Treatise on Internet-Distributed Television. Ann Arbor: University of Michigan, 2017.

Macrotrends. "Internet Services: Top Stocks." 2019. https://www.macrotrends.net/stocks / research (accessed June 18, 2019).

Mickle, Tripp. “Apple Builds \$1 Billion Hollywood War Chest." The Wall Street Journal, August 17, 2017, p. A1.

Miége, Bernard."Cultural and Creative Industries and the Political Economy of Communication." In Making Media: Production, Practices and Professions, edited by Mark Deuze and MirijamPrenger, 73-84. Amsterdam: Amsterdam University Press, 2019.

Miége, Bernard. "The Logics at Work in the New Cultural Industries." Media, Culture E Society 9, no. 3 (1987): 273-89. doi:10.1177/016344387009003002. 
Mudra Institute of Communications, Ahmedabad. Indian OTT Platforms Report 2018. Ahmedabad: Mudra Institute of Communications, Ahmedabad, 2018.

Mukherjee, Rahul. "Jio Sparks Disruption 2.0: Infrastructural Imaginaries and Platform Ecosystems in 'Digital India." Media, Culture and Society 41 (2019): 175-95. doi:10.1177/ 0163443718818383.

Mukherji, Rahul. "The Politics of Telecommunications Regulation: State-Industry Alliance Favouring Foreign Investment in India." The Journal of Development Studies 44, no. 10 (2008): 1405-23. doi:10.1080/00220380802358499.

Mundy, Simon. "Amazon and Netflix Study India's Rule Book; USRivals Hope a Strategy that Includes Glitzy Cricket Dramas Can Persuade Frugal Consumers to Sign up in a Flooded Market." Financial Times, September 9, 2017.

Mundy, Simon. "Netflix to Make First Original Series in India." Financial Times, June 6, 2016.

Mundy, Simon. "Reliance to Take on Amazon and Flipkart in Indian Ecommerce." Financial Times, January 18, 2019.

Narayan, Vikram Aditya, and Raka Arya. "Regulation of New Media: The Indian Scenario." In India Connected: Mapping the Impact of New Media, edited by Sunetra Sen Narayan and Shalini Narayanan, 143-70. Thousand Oaks, CA: SAGE, 2016.

Nicas, Jack. "YouTube's Focus Is Being a Platform, Not Producing Premium Content, CEO Says." The Wall Street Journal, October 26, 2016.

Parbat, Kalyan. "Telcos Slam Trai Views on Net Neutrality, Term Move to Set up a Monitoring Body 'Draconian."' The Economic Times, November 29, 2017.

Parthasarathi, Vibodh, Arshad Amanullah, and Susan Koshy. "Digitalization as Formalization: A View from Below." International Journal of Digital Television 7, no. 2 (2016): 155-71. doi:10.1386/jdtv.7.2.155_1.

Parthasarathi, Vibodh, Alam Srinivas, Archna Shukla, Supriya Chotani, Anja Kovacs, Anuradha Raman, and Siddharth Narain. "Mapping Digital Media: India." 2012. http://www .opensocietyfoundations.org/reports/mapping-digital-media-india.

Pendakur, Manjunath. "Twisting and Turning: India's Telecommunications and Media Industries under the Neoliberal Regime." International Journal of Media \& Cultural Politics 9, no. 2 (2013): 107-31. doi:10.1386/macp.9.2.107_1.

Punathambekar, Aswin, and Sriram Mohan. "Digital Platforms, Globalization and Culture." In Media and Society, edited by James Curran and David Hesmondhalgh, 207-26. London: Bloomsbury, 2019.

Ramachandran, Naman. "Netflix and Amazon Take Different Sides on Content Regulation in India." Variety, January 17, 2019.

Ramachandran, Naman. "Reliance Industries Spends \$712 Million on Cable and Broadband Acquisitions." Variety, October 19, 2018.

Ramachandran, Shalini. "Amazon Video to Go Global." The Wall Street Journal, November 18, 2016a, p. B2. 
Ramachandran, Shalini. "Netflix, Amazon Take Divergent Paths to Reach Indian Audience: Netflix Is Relying on Its Global Programming, While Amazon Is Betting on Going Local with Its Video Streaming Service." The Wall Street Journal, November 1, 2016b.

Sabherwal, Simran, and Allan Dsouza. “OTT: AVoD vs SVoD.” Impact 48, no. 48 (2017). http:// www.impactonnet.com/node/5300.

Schiller, Dan, and ShinJoung Yeo. "Science and Engineering in Digital Capitalism." In Routledge Handbook of the Political Economy of Science, edited by David Tyfield, Rebecca Lave, Samuel Randalls, and Charles Thorpe, 70-82. Abingdon: Routledge, 2017.

Seetharaman, Deepa. "Facebook Embraces 'Video-First' Future-Company Looks to Spend Heavily on Original Content to Capture More Eyes." The Wall Street Journal, September 9, 2017, p. B1.

Simhan, Raja. "YouTube Eyes Regional Flavour." The Hindu Business Line, October 18, 2012.

Soni, Aayush. "India Deals Blow to Facebook in People-Powered 'Net Neutrality' Row." The Guardian, February 8, 2016.

Spangler, Todd. "Netflix Original Content Outscores HBO, Hulu, Amazon on CustomerSatisfaction Survey." Variety, February 21, 2019.

Spangler, Todd. "Netflix Stock Shoots to Record Highs as Investors Embrace Cash-Burn Strategy." Variety, July 18, 2017.

Spangler, Todd. "Netflix Targeting 50\% of Content to Be Original Programming, CFO Says." Variety, September 20, 2016.

Spangler, Todd. "Police Make Arrests in 'Game of Thrones' Piracy Case in India." Variety, August 14, 2017.

Spangler, Todd. "YouTube to Make New Originals Available for Free, Ad-Supported Viewing with 'Single Slate' Strategy." Variety, November 27, 2018.

Szalai, Georg. "Disney, Comcast to Dominate Global Content Spending, Study Says." The Hollywood Reporter, December 10, 2018.

Telecom Regulatory Authority of India. Consultation Paper on Net Neutrality. New Delhi: Telecom Regulatory Authority of India, 2017a.

Telecom Regulatory Authority of India. Consultation Paper on Regulatory Framework for over-the-Top (OTT) Services. New Delhi: Telecom Regulatory Authority of India, 2015.

Telecom Regulatory Authority of India. The Indian Telecom Services Performance Indicators. New Delhi: Telecom Regulatory Authority of India, 2017b.

Thakurta, Paranjoy Guha. "What Future for the Media in India?" Economic \& Political Weekly 49, no. 24 (2014).

Thakurta, Paranjoy Guha, and Subi Chaturvedi. "Corporatisation of the Media: Implications of the Ril-Network18-Eenadu Deal." Economic \& Political Weekly 47, no. 7 (2012): 10-13. https://www.jstor.org/stable/41419787. 
Thakurta, Paranjoy Guha and Aditi Roy Ghatak. "The Immaculate Conception of Reliance Jio." The Wire, March 6, 2016. https://thewire.in/tech/the-immaculate-conception-ofreliance-jio.

The Economic Times. "Sony to Move Its Video Streaming Service Sony LIV to a Fee-Based Model." August 31, 2015.

The Pioneer. "The YouTube Onslaught." November 18, 2012.

Thomas, Pradip Ninan. "Infrastructure and Platform Anxieties in India." In Digital Transactions in Asia, edited by Adrian Athique and Emma Baulch, 44-62. New York: Routledge, 2019.

Tiwary, Ishita. "Amazon Prime Video and the Indian Media Market: A Platform Ecosphere." Media Industries Journal (2019).

Waters, Richard, Kuchler, Hannah \& Shannon Bond. "Silicon Valley: Big Tech Prepares for Its Second Act." Financial Times, August 4, 2018, p. B11.

Williams, Raymond. Television: Technology and Cultural Form. 2nd ed. London: Routledge, 1990.

Winseck, Dwayne. "The Geopolitical Economy of the Global Internet Infrastructure." Journal of Information Policy 7 (2017): 228-67. https://www.jstor.org/stable/10.5325/ jinfopoli.7.2017.0228.

Winseck, Dwayne. "The Political Economies of Media and the Transformation of the Global Media Industries." In The Political Economies of Media: The Transformation of the Global Media Industries, edited by Dwayne Winseck and Dal Yong Jin, 3-48. London: Bloomsbury, 2011. 
